\title{
GOVERNMENT, CO-OPERATIVES AND PEASANT AGRICULTURE IN KENYA
}

\section{Geoff Lamb*}

Co-operatives are important in Kenya. But, it might be argued, they are not that important: why should they be made a focal point of research into agrarian change and government strategy towards the peasantry?

The answer, for present purposes, is that the co-operative structure is both the means chosen by the Kenyan government for integrating the peasantry (or sections within it) into the "modern" capitalist economy, and secondly, very of ten the most visible and important means of political and economic mobility for ambitious peasants. Marketing co-operatives are not of course the only means of accomplishing these varying ends - for example they do not yet exist, on the whole, where there is not an established peasant-grown cash crop - but there is no doubt that in the Kenyan context they fulfil those needs where crucial crops and regions of the country are concerned, and they provide a vital mechanism of political control and political advancement for important sections of rural society. ${ }^{1}$ The problems which research must engage in this field, therefore, are at two levels.

Firstly, and in the long run more importantly, one must be able to evaluate the Kenyan co-operative movement's role as a mediating or articulating mechanism, in terms of its role in the transformation of non-capitalist modes of production in the rural areas of Kenya. Here the analysis would centre on the extremely complex interaction between the dominant capitalist and the non-capitalist modes, particularly in terms of differing social divisions of labour and of class formation, and in terms of the central importance of state institutions in controlling the process.

* Geoff Lamb is a Fellow of the Institute.

1 See e.g. Lamb, Peasant Politics, (Julian Friedman, London, 1974). Chapters V and VI. 

IN KENYA

But secondly, this overall analysis of the structure of social relations needs to come to grips with the question of policy: i.e. to what extent should various government policies, and particularly those in the agricultural sector, be seen as embodying coherent socio-political strategies? And, to the extent that they can be so seen, what is the relationship between those ends and what actually happens? The importance of this latter point, of course, is not to point to obvious and inevitable disparities, but to clarify the way in which both institutional processes and other processes of economic and political change are actually changing the pattern of Kenyan peasant life, and therefore what new problems are developing for the state as it tries to control rural events. This article discusses some issues arising out of this second point.

There is not too much difficulty in sketching the general direction of Kenyan agricultural strategy since independence. Government policy has been one of adapting the colonial structure of agricultural production by the removal of the two most glaring anomalies, but otherwise by encouraging growth within the established framework. Thus the late colonial period saw the progressive removal of the legal and administrative obstacles to the participation of Africans in cash crop production, while the central feature of agrarian policy in the first years of independence was the establishment of some 35,000 African families on over one million acres of formerly white settler-owned land, generally at densities far lower than those obtaining in the African reserves. These measures not only encouraged a very rapid rise in African small farm (i.e. peasant) production within a decade to approximately half the total marketed agricultural output, but also in effect provided political protection for the capitalist farm sector, which has become Africanized to a considerable degree in the decade since independence. The independent government, in addition, has adopted and extended the late colonial policy of "reproducing the peasant mode of production" by a land consolidation and registration which has rationalised and stabilised existing patterns of distribution, and provided the basis in tenure for extension and credit policies which have up to now likewise operated decisively in favour of wealthier peasants - that is, to the relatively small extent that extension and credit was not concentrated in the capitalist farm sector! 
But when one turns to the institutions concerned with agrarian policy, the picture becomes very complicated indeed. Aside from the co-operative movement, there is the whole elaborate parastatal structure of marketing and processing boards and agencies, each with its own bureaucracy, each enjoying legally and administratively defined areas of predominance or monopoly, each standing in a particular relationship to peasant and other producers, to the international economy, and to the régime and its clients. There is the overwhelming presence of the administration (that is, of the general administrative service under the office of the president) in the rural areas, with the district commissioners wielding wide but sometimes unclear administrative and political power over other government agencies and over the rural population. And there are the technical ministries, especially of course agriculture, and functions like that of community development which are important in terms of government control over potentially autonomous social organisation, and as a "welfare" element for the benefit of those left out by the rich-peasant orientation of agricultural policy.

Government's relationships with the co-operative movement in Kenya have for long been characterised by considerable ambiguity an ambiguity which reflects, as much as anything, the uncertain role which co-operative societies play in Kenyan peasant society. Until some time after the last war, the colonial government viewed African co-operatives with profound suspicion, for precisely the same reasons that any worthwhile advance in African agriculture was unwelcome and often suppressed: that substantial agricultural advance in the African areas represented a threat to the interests of the settler community and to the interests of the colonial administration in terms of economic changes and a potential threat to political control. A major reason for the change in governmental attitudes towards co-operatives, of course, has been the advent of independence and a new kind of emphasis on rural development: but in one respect which is extremely germane to the present problems of the Kenyan movement, that change stems from the bureaucratic requirem ents of the terminal colonial period, from the need for continuing an efficient state control over the Kenyan peasantry.

In many areas of Kenya, including such high-production regions as Central Province, co-operatives have come into being less as a 
response to exploitation by middlemen (as in the Uganda cotton case, for example), but more often because of direct administrative encouragement and to fulfil clear administrative needs. Particularly during the late 1950 s, there were undoubtedly "idealistic" colonial administrators - district officers, agriculturists and others -- who saw co-operatives as a means of community development and equitable control of the new economic opportunities in the Kenyan countryside. At the same time, however, co-operative development fell into a category of devices which needed to be used to control the countryside: particularly in Central Province, co-operatives were integrated into the colonial strategy of re-making the social structure of African society, by altering the basis of land tenure, by encouraging the introduction of cash crops which had hitherto been effectively unavailable to Africans - a strategy, in short, designed to maximise the state's ability to control events in the countryside, by endowing the administration with desirable resources (registration, credit, extension, etc.) which the upper sectors of the re-structured peasantry could utilise. To the extent that the colonial strategy in the rural areas in the 1950 s was designed as a political weapon to counteract the influence of nationalism, it clearly failed: in the process, however, there had grown up an impressive structure of state influence in the peasant areas which has continued and indeed expanded up to the present - administrative and technical agencies with wide powers over individual farmers, an elaborate structure of state marketing boards, far-reaching statutory powers over rural institutions such as co-operatives.

Thus, while the Kenyan government has emphasised individual enterprise and achievement, and has been happy to see the emergence of private entrepreneurs in the countryside and in urban areas, it has nevertheless inherited and expanded a considerable capacity for controlling agricultural life. Even the colonial co-operative ordinance, which provided for a considerable degree of government control of co-operative societies, has been succeeded by new legislation (Co-operative Societies Act 1966) giving government even wider powers of control. The commissioner of co-operative development is given powers of registration, dissolution and compulsory amalgamation over co-operative societies, power to supervise budgets, approve the hiring and dismissal of graded staff, 
and approve society bye-laws and resolutions, to control financial transactions through the counter-signature of cheques and other instruments, and sundry other powers to ensure that co-operatives are run in an honest and efficient manner. Co-operatives are thoroughly integrated into the state marketing board system, and at the same time state and co-operative control over individual farmers greatly extended, by the provisions allowing the minister to require all producers of a particular crop to dispose of it through the co-operatives, provided only that the co-operatives in that area (or throughout the country) can show that their members produce not less than $60 \%$ of the crop.

There are thus very strong pressures on farmers to join co-operatives, in many cases, and these are backed up in some areas by better access to credit, extension, and other services for co-operative members than for "private" smallholders. The full import of these pressures, and of the ramifications of the co-operative cum state marketing structure, become apparent when the extent of the powers which co-operative societies in Kenya have over their members is indicated. Societies may, for example, enter into contracts with outside bodies which entail pledging the produce of its members as security; they may fine members for disobeying the bye-laws of the society; they may contract with members to produce and sell through the society a specified amount of produce, and exact damages for failure; they exercise preferential charges over members' goods and chattels for the discharge of debts to the society. ${ }^{2}$

\section{Co-operative Leadership}

It is quite clear that members' rights of attending general meetings and electing alternative managements do little to constrain the potential of such wide powers. Given not only the bureaucratic origins, in many cases, of Kenyan co-operatives, but also continuing state determination to exercise even closer control over the societies - hence over the economic affairs of thousands of peasant farmers the nature of the relationship between government and the local

2 There is an excellent critical summary of the legislation by J.P.W.B. McAuslan in Co-operatives and Rural Development in East Africa, edited by Carl Gosta Widstrand, Scandinavian Institute of African Studies, Uppsala, 1970. 
co-operative leaderships assumes crucial importance. The questions thus not only revolve around whether co-operative management committees are oppressing their memberships in any way (by cheating them, or by wasting their proceeds, for example), but whether the role of government improves the position of the peasantry vis-à-vis its local leaders, aggravates smallholders' problems, or simply makes very little impact specifically in the field of co-operative reform.

This specific government role of interceding, in one way or another, between peasant co-operative members and their management committees has for long been identified by the government itself as central to the task of co-operative reform, as we shall see. But why? Plainly, because the richer peasants who control the co-operatives have been dishonest, or incompetent, or both, and because they have used the co-operatives as instruments of political power in the rural areas. Government determination to rid the movement of corruption and incompetence, of course, stems from the fact that these shortcomings are extremely bad for efficiency, for "morale", for commitment, as well as grossly inequitable; its opposition to the politicisation of the co-operatives is more an aspect of the characteristic Kenyan concern with close political and administrative control of the countryside, than to do with specific opposition to the kulaks.

Since we are here less concerned with the nature of specific counter-measures than with the social and political environment which produces these problems, it is perhaps not necessary to itemise the different kinds of fraud and mismanagement which are quite common features of Kenyan primary societies. Some examples which illustrate the difficulties of control, however, might perhaps be mentioned here. One of the flagrant abuses which the 1966 Co-operative Societies Rules set out to check was the profligate issuing of loans and other payments to committee members, their relatives, or their clients. Hence, in part, the requirement that the district co-operative officer and the secretary-manager of the district co-operative union should countersign all cheques. What has happened in many cases, however, is that management committees have mitigated the effect of this provision (where it was being 
effectively enforced) by ensuring that societies built up as large a cash balance on the premises as possible, from members' payments and the like, to avoid uncomfortable supervision of the more profitable part of their financial dealings. Holding large sums of cash also allowed corrupt committees to circumvent the rule requiring all supplies to be ordered through the union, and not by private arrangements with local wholesalers. The incentive to continue buying such supplies as fertiliser, building materials, and the like - at much higher prices than the union, with its large orders and more open tendering and ordering methods, could offer - stems from the "personal discount" system, whereby committee members in effect split the difference between local price and union price with the local wholesaler.

In many other areas - such as the preferential grading of committee members' produce, or the pressuring of primary society hired staff to acquiesce in corrupt practices - the reforms effected in 1966 and since then have undoubtedly had a beneficial effect. The experience of recent years has also served to demonstrate, however, that co-operatives are far less amenable to control, which is the sense in which reform has been defined in Kenya, than had earlier been thought. What has emerged as a central feature of co-operative problems, in other words, has not, by and large, been susceptible to reform by the available methods: the crucial problem, that is, has been the domination of co-operative societies by the most powerful elements in the rural areas. The reasons for this dominance are as simple as the mechanisms whereby dominance is maintained are complex: co-operative societies control economic resources, access to valued people and services, and the opportunity for political advancement, all of which will be eagerly sought and bitterly fought over in any poor community. What is less obvious is the nature of the connections between the co-operatives and the institutions alongside which they operate, or which they at times disrupt and displace, and it is here that efforts to effect reform often produce unintended consequences.

The problem of co-operatives operating to the advantage of the richer peasants and against the interests of the poorer thus has much to do with the fact that co-operatives were assiduously encouraged 

IN KENYA

by government agencies, in a situation where they merely provided yet another avenue for the entrepreneurial activities of aspirant kulaks. As Guy Hunter has said:

“. . . such institutions as co-operatives, farmers' clubs or associations, have to be formed with the greatest political care. The safest (and often the most successful) form of co-operative is based on a clear technical reason - the sharing of a single tubewell by a few small farmers, the common use of storage, dairy equipment, etc. The most politically and socially fatal is the general fiat 'let co-operatives be' which is an open invitation to the old hierarchy to capture them."3

Co-operatives in Kenya, therefore, have been caught between the desire of government for control over the agricultural surplus (and its choice of co-operatives as one appropriate mechanism), and the alacrity of rural leaderships in seizing on this new institution as a means of increasing income and augmenting political power. At the same time, of course, government itself is intimately connected with rural powerholders, and to the extent that co-operative reform really damages the position of rural political-economic elites, one can expect strong pressures for change in policy. What must be seriously questioned, therefore, is whether the solution to what has emerged as a primarily political problem can realistically be sought in the series of administrative and educational measures currently being undertaken or envisaged.

\section{Administrative Control as a Political Strategy}

It can be persuasively argued that administrative control as a technical solution to co-operative problems has already failed - if only because of the fact that it has been put forward as the most desirable strategy at least since 1966 and the Co-operative Societies Act, and to a considerable extent even before that (e.g. in colonial warnings about the need for "careful supervision"). Certainly the emphasis in government policy has since 1966 been on developing administrative capacities to regulate, supervise, merge, and in general

3 "Agriculture and Social Development" in A.H. Bunting, ed., Change in Agriculture. Duckworth, London, 1970, p. 33 . 
control co-operatives, not only in the 1966 Act and Rules but in the Development Plan, ${ }^{4}$ and in policy statements ${ }^{5}$ and reviews of performance $^{6}$, where administrative expansion and the increase of administrative expertise is treated as a priority. If close control and supervision are so vital, and yet so difficult to achieve, what is the particular advantage of co-operatives as instruments of rural development? It would seem that the problems so far encountered in extending official capacity are so serious, and yet the impetus to go on trying so great, that the theoretical saving in government manpower and expertise (and investment) which co-operatives should effect, is largely lost. At the same time, other costs are being incurred - it cannot be beneficial for either government or the co-operative movement for peasants to perceive primary societies and district unions as a part of the bureaucratic structure, as in many instances they clearly $\mathrm{do}^{7}-$ or at least not beneficial in conventional terms.

Thus the co-operative élites have suffered the closure of some of their opportunities for enrichment, and attempts to devalue their local influence by enhancing the powers of district unions (as well as government officials), without their dominance of primary societies being in any way fundamentally challenged. The employees of co-operative societies, while they have been given some security of tenure (in that government consent to the dismissal of graded staff is required), have likewise been subjected to increasing intervention and declining opportunities for increasing their income, without being provided with one of their perceived needs, a career structure which provides a real incentive for honest and efficient management and the learning of more advanced skills. At the same time, rank and file members of primary societies have as yet little reason to change their view either of their societies or of the bureaucratic structure which

4 Development Plan 1970/74, pp. 276-81.

5 Co-operative Development Policy for Kenya, Sessional Paper 8/1970.

6 E.g. Economic Survey 1971, pp. 74/5, and the Dept. of Co-operative Development's own 1972 Plan.

7 Especially in the case of the district co-operative unions, which government is deliberately transforming into an instrument for enforcing policy - see Development Plan 1966/70, pp. 201. 
supervises it. They still have little effective choice about joining a co-operative, given that they desire access to certain crops and accompanying services, and they still lack any real opportunity (or knowledge) to change the faction- and patronage- dominated leadership styles in the societies. Whatever officials of the Department of Co-operatives achieve through increased supervision, it is not an increase in the autonomous capacity of ordinary peasants to control their institutional environment. And, of course, issues of motivation, of the "communal good" and the "co-operative spirit", do not even begin to become relevant in this situation.

But here, of course, we return to the distinction between formally stated policy aims and the impact of policy. It is reasonable to suppose that the Kenyan government is concerned to "clean-up" co-operatives: it is not reasonable to suppose that in doing so the regime is prepared to confront the holders of political and economic power in the countryside. But, intriguingly, the matter is not quite as simple as that.

The cumulative impact of the state's agrarian strategy, which was referred to at the outset, is to underline and in many circumstances to exacerbate inequality and social differentiation. This is equally true in the co-operatives. The distribution of income between co-operative members is generally highly unequal - especially where well-established and high-value crops such as coffee are concerned, where inequalities of coffee income between the top $15-20 \%$ of members and the rest are likely typically to run at a factor of 10 to 1 in terms of the average income in each group. Furthermore, capital levies, political contributions, "voluntary" donations - such as the huge donations for the district-based Colleges of Advanced Technology currently being sponsored in Kenya - are steeply regressive, since they usually involve across-the-board equal deductions from individual members' proceeds.

At the same time, however, there are two factors which militate against the co-operatives, at any rate, operating to promote rural capitalism on any appreciable scale. Firstly, since leadership in the co-operatives is predominantly a political affair - i.e. it demands the construction of political followings and their maintenance on a more 
or less mercenary basis - the legal and illegal benefits of leadership tend to be rather expensively won, and the surplus for accumulation and investment in productive activities is limited to that extent. One might also point out, here, that costs of marketing for peasants in Kenya tend to be rather high because of the very elaborate parastatal marketing structures which are financed from gross crop proceeds: a sizable part of the peasant surplus is therefore creamed off directly by various sections of the state apparatus.

Secondly, the co-operatives, as we have seen, form part of the developing structure of state control in the Kenyan countryside, and that control has also been deployed to ensure that social disruption is kept at a minimum. Thus the administration places great emphasis not only on obedience, but on social cohesion and group activity (like self-help) under state auspices, while the more flagrant kinds of accumulation (like evictions) are simply disallowed in many cases, irrespective of the sanction of law. The effect of policy toward the co-operative movement in recent years has been consistent with this tendency, in that disruption of production and possible political conflict have been averted by curbing obvious excesses and by incorporating co-operatives more firmly into the state machine, while the dominant position of the peasant leadership has not been seriously threatened.

It has been argued in recent years in Kenya that this situation precludes full advantage being taken of the productive possibilities of peasant agriculture: the implication is that would-be agrarian capitalists are waiting to emerge from the peasant masses once the institutional shackles are removed. This may be: the more relevant point, however, is that co-operatives are so important, to state and peasantry alike, precisely because they provide avenues of economic mobility (for some) so far without the widespread development of capitalist relations of production and ensuing patterns of class formation. Capitalist development in Kenya is not, on the whole, taking place within the peasant areas, but outside them. What is happening in most of the rural areas is differentiated development of agriculture on a basically peasant basis under conditions of tight political control. The quiescence of the rural areas is thus for the present dependent on the maintenance of that control and, by 
36 GOVERNMENT, CO-OPERATIVES AND PEASANT AGRICULTURE IN KENYA

implication, on the preclusion of rapid transformation of the social relations of production, particularly in the politically sensitive areas where peasant cash crop production is well established. Hence Kenyan rural development policy has laid increasing emphasis on bringing the more backward areas in to the cash economy - i.e. to commercialise them rather than introduce new forms of production - concurrently with the extension of communications and administrative facilities.

Whether the "controlled peasant economy" strategy can continue to work in the more advanced areas, however, is open to some degree of question, particularly in times of production difficulties and, in some areas, incipient food crises. In these circumstances, the co-operatives assume a wider political significance: despite their partial subordination to administrative control, they nevertheless offer the only current means of political mobilisation to crucial sections of Kenya's upper and middle peasants. The point is not that the co-operatives might become insurrectionary: they will not. The development of widespread political struggle within them, however, may well be a sign that the political arrangements for containing rural change within manageable bounds are breaking down. 